\section{OPEN ACCESS}

Edited by:

José M. Alvarez-Suarez,

University of the Americas, Ecuador

Reviewed by:

Diego A. Moreno,

Spanish National Research

Council, Spain

Manuel Viuda-Martos,

Universidad Miguel Hernández de

Elche, Spain

${ }^{*}$ Correspondence:

Rosa Palmer

rpalmeri@unict.it

Specialty section

This article was submitted to Nutrition and Food Science Technology,

a section of the journa

Frontiers in Nutrition

Received: 05 November 2018 Accepted: 23 March 2020

Published: 16 April 2020

Citation:

Caggia C, Palmeri R, Russo N, Timpone R, Randazzo CL, Todaro A and Barbagallo S (2020) Employ of Citrus By-product as Fat Replacer Ingredient for Bakery Confectionery

Products. Front. Nutr. 7:46

doi: 10.3389/fnut.2020.00046

\title{
Employ of Citrus By-product as Fat Replacer Ingredient for Bakery Confectionery Products
}

\section{Cinzia Caggia ${ }^{1}$, Rosa Palmeri ${ }^{1 *}$, Nunziatina Russo ${ }^{1}$, Rosario Timpone ${ }^{2}$, Cinzia L. Randazzo ${ }^{1}$, Aldo Todaro ${ }^{3}$ and Salvatore Barbagallo ${ }^{1}$}

${ }^{1}$ Di3A - Dipartimento di Agricoltura, Alimentazione e Ambiente, University of Catania, Catania, Italy, ${ }^{2}$ Citrech, Viale Regina Margherita, Messina, Italy, ${ }^{3}$ SAAF - Dipartimento di Scienze Agrarie, Alimentari e Forestali, University of Palermo, Palermo, Italy

Citrus fruits processing is one of the foremost industrial activities in Sicily and the main residual by-product consists in peels and seeds (known as "pastazzo"). Traditionally this by-product has been used for different purposes, and only most recently, it has been described as source of a wide range of healthy bioactive compounds and dietary fibers. In the present work, a debittered food grade orange fiber (DOF), extracted from orange juice by-product, was experimentally obtained and tested as fat-replacer at different percentages $(30,50$, and $70 \%$ ) in bakery confectionery products (brioches). The DOF showed high total fiber content, low water activity and a high water binding capacity. The obtained bakery products were characterized for nutritional, technological and microbiological parameters through storage at room temperature. Results highlighted that the addition of DOF results in final products with increased moisture content, mainly after 1 day of storage, and good textural proprieties. Furthermore, the fat-replacing strategy, at different levels of DOF, resulted in final products with, besides a constant content of carbohydrates, showed lowered fat content, increased content of dietary fiber and protein. In particular, the 50\% fat replacement allowed to obtain brioches with improved technological properties and with desirable microbiological traits, mostly within the first $24 \mathrm{~h}$ from production and up to 5 days of storage.

Keywords: orange juice waste, bakery confectionery products, functional foods, dietary fiber, fat replacement

\section{INTRODUCTION}

In recent years, consumers' interest for healthy food has addressed the industry to review nutrient quality of product portfolios in order to offer products with reduced fat content (mainly saturated ones), sugar and salt added, through the addition of functional ingredients and the improvement of technological characteristics $(1,2)$. Several studies have showed that the adding of ingredients of plant origin allows the increase of nutritional value of final products and, generally, provides a health benefit, for their antioxidant content and proteins of high biological value $(3,4)$. Furthermore, food-products fortified by natural ingredients are greatly acceptable by consumers, especially by those more sensitive to environmental matter. Vegetable waste and vegetable byproducts could be converted into edible ingredients and therefore should be regarded as a source of valuable components (5). 
Citrus is one of the main fruit crops in the world, with an estimated production higher than 170 million tons, among which the $58 \%$ is represented by oranges (6). Italy is, after Spain, the main citrus producing country in the Mediterranean basin, and the two countries covered the $80 \%$ of the European production [USDA (7)]. In Sicily, an average of $34 \%$ of citrus fruits are processed into juices providing about a half of its weight as waste (8), which reaches 24.3 million tons per year (9). Citrus waste is mainly constituted by peels (albedo and flavedo), seeds, fruit pulp and essential oils (10) and its disposal represents an environmental concern. In this contest, several efforts have been done in different fields, suggesting citrus waste as fertilizer, feed ingredient, source for several compounds extraction (11) mainly soluble sugars, organic acids, amino acids, proteins, minerals, oils, lipids, vitamins, essential oils, pectin, or matrix for bio oil, charcoal production, and heavy metals decontaminant (12). More recently, citrus waste has been recognized as a potential source of bioactive compounds, such as flavonoids $(13,14)$ and dietary fiber $(15,16)$. Based on water solubility, fibers are distinguished into soluble (oligosaccharides, pectins, $\beta$-glucans, and galactomannan gums alginate, psyllium) and insoluble (cellulose, hemicellulose, and lignin) (17-19). Insoluble fiber seems to play an important role in the prevention and treatment of obesity, atherosclerosis, coronary heart diseases, diabetes, hemorrhoids, hypercholesterolemia, diverticular disease and colon cancer (20). Moreover, the majority of insoluble fiber is fermented in the large intestine, supporting the growth of beneficial intestinal microbiota. Its employment, alone or in association with other micronutrients, such as omega-3 fatty acids, phytosterol and probiotics $(21,22)$, affects functional and technological traits of several kinds of food, such as meat products (11), bread, biscuits, cookies, ice-cream (23) soft drinks and pasta $(5,24,25)$. Furthermore, fortifying bakery products by adding ingredients of vegetable origin, in a final amount higher than 5\% (high biological value), has encouraged several studies on products containing different functional ingredients.

Bakery confectionery products (as brioches) are complex foods, containing, beyond the main ingredients (flour and water), other optional ingredients such as salt, sugar, leaven, lipids, eggs, etc., in different proportions. The used ingredients make brioches highly caloric, bringing to diet significant amounts of complex carbohydrates, sugars and fats. However, each added ingredient, according to a particular sequence and in combination with subsequent technological steps, contributes to texture and shelf life of final products.

The aim of the present study was to produce a debittered orange fiber (DOF) powder and to be employed as fat replacer in the production of fiber fortified bakery confectionery products (brioches). Physico-chemical, nutritional and technological characteristics of obtained samples were determined and shelf life was evaluated up to 5 days.

\section{MATERIALS AND METHODS}

\section{Production of Debittered Orange Fiber}

The debittered orange fiber (DOF) was obtained through several steps in a pilot scale process set up within the project
"Uso sostenibile dei sottoprodotti provenienti dalla lavorazione industriale degli agrumi" founded by Ministero dello Sviluppo Economico (data not published). Peels from fruit processing line ("pastazzo"), were firstly crushed through hammer mills and a paddle finishers. The peels were then washed, for three times in upstream, and debittered by an alkaline solution $(\mathrm{NaOH})$ at different times $(30,60,90$, and $120 \mathrm{~min})$ to remove sugars, flavonoids and limonoids. After removing bitter liquids from peels, they were neutralized by a citric acid solution and finally raw pressed and dried using a fluid-bed dryer. Dried peels were coarsely milled by an hammer mill and reduced in powder with a mill up to a final mesh of $50 \mu \mathrm{m}$.

The waste waters were evaluated for content in limonin, according to 26). The main characteristics of the obtained insoluble DOF are shown in Table $\mathbf{1 .}$

\section{Characterization of Debittered Orange Fiber}

The DOF were tested for weight, moisture and activity water (Aw). The weight was evaluated by an analytical balance (Gibertini). Moisture content was determined by automatic moisture analyzer (Gibertini) at $110^{\circ} \mathrm{C}$, while, Aw was determined by AquaSorp Isotherm Generator (Decagon) at $25^{\circ} \mathrm{C}$. Analyses were carried out in triplicate at T0, T1, and T5 sampling times. The total phenolic content (TPC) of DOF was determined according to Singleton and Rossi (26) method, using the Folin-Ciocalteau reagent (FC). An aliquot of the extract (250 $\mu \mathrm{L})$ was mixed with the FC reagent $(1.25 \mathrm{~mL})$ and allowed to react for $3 \mathrm{~min}$, then $2.5 \mathrm{~mL}$ of $2 \%$ sodium carbonate $\left(\mathrm{Na}_{2} \mathrm{CO}_{3}\right)$ was added. The mixture volume was adjusted to $25 \mathrm{~mL}$ with distilled water and allowed to stand in the dark for $1 \mathrm{~h}$. The absorbance was measured at $725 \mathrm{~nm}$ (Perkin Elmer lambda 25 UV-VIS spectrometer) and results were expressed as mass of gallic acid equivalents ( $\mathrm{mg} / \mathrm{g}$ fresh weight).

\section{Brioches Preparation}

Brioches, common bakery confectionary products, were prepared according to traditional methods in an artisan confectionary, located in Acireale, south Italy. The recipe used for conventional

TABLE 1 | Physico-chemical characteristics and composition of DOF.

\begin{tabular}{lc}
\hline Parameter & Value \\
\hline Moisture & $7.85 \pm 0.02 \mathrm{~g} / 100 \mathrm{~g}$ \\
Ash & $5.67 \pm 0.15 \mathrm{~g} / 100 \mathrm{~g}$ \\
Dietary fiber & $70.5 \pm 1.0 \mathrm{~g} / 100 \mathrm{~g}^{*}$ \\
Pectin & $1.60 \pm 0.10 \mathrm{~g} / 100 \mathrm{~g}^{*}$ \\
Pectin ossalate soluble & $0.65 \pm 0.02 \mathrm{~g} / 100 \mathrm{~g}^{*}$ \\
Pectin water soluble & $0.90 \pm 0.02 \mathrm{~g} / 100 \mathrm{~g}$ \\
Water binding capacity & $800 \pm 40 \%$ \\
Activity water (Aw) & $0.24 \pm 0.01$ \\
Limonin & $<2 \mathrm{mg} / \mathrm{kg} \mathrm{of} \mathrm{fiber}$ \\
Total polyphenols & $<100 \mathrm{mg} / \mathrm{kg}^{* \star}$ \\
\hline
\end{tabular}

*expressed as galacturonic acid; ** expressed as esperidin. 
brioches (here considered as control: CTR), based on $1 \mathrm{~kg}$ wheat flour, provided for fat $(220 \mathrm{~g})$, sugar $(250 \mathrm{~g})$, leaven $(20 \mathrm{~g})$, eggs (5), and salt. Experimental brioches (EB) were obtained replacing fat content, at different percentages (30, 50 and 70\%) with DOF. Samples were produced between March and July 2018, and stored in sealed bags at room temperature. Physico-chemical and nutritional characteristics were determined starting from the same day of production (T0), after 1 day (T1) and after 5 days (T5).

\section{Determination of Physico-Chemical Parameters}

Samples of CTR and EB, obtained with different fat percentage replacements, were tested for weight, moisture and activity water (Aw).

The weight was evaluated by an analytical balance (Gibertini). Moisture content was determined by automatic moisture analyzer (Gibertini) at $110^{\circ} \mathrm{C}$, while, Aw was determined by AquaSorp Isotherm Generator (Decagon) at $25^{\circ} \mathrm{C}$. Analyses were carried out in triplicate at T0, T1, and T5 sampling times.

\section{Proximate Composition of Debittered Orange Fiber}

The total dietary fiber was determined in accordance with AOAC 991.43 method, using the enzymatic assay kit Total Dietary Fiber (Megazyme International Ireland Ltd, Wiclkow), following the manufacturer's instructions.

\section{Determination of Fat Content}

Fat content was determined according to Official Method (27). Briefly, two grams of each sample were grinded and hydrolyzed using chloridric acid. Fats were extracted with a mixture of equal volumes of ethyl ether and petroleum ether and subsequently weighed after removal of the solvent. The extraction was repeated three times, at the end of which the solvent was removed by evaporation to constant weight of the sample.

\section{Determination of Protein Content}

Protein content (Nx5.7) was assessed according to the Official Method (27), by a semiautomatic Kjeldal apparatus (Velp UDK139). Briefly, two grams of grinded sample were mixed with $20 \mathrm{ml}$ of sulphoric acid (98\%), mineralized at $420^{\circ} \mathrm{C}$ for $60 \mathrm{~min}$, two Kjeldahl tablets of $5 \mathrm{~g}$ were used as catalyzer agent. The digested sample was diluted with $100 \mathrm{ml}$ of distilled water, transferred in the distillation unit added with $50 \mathrm{ml}$ of sodium hydroxide $(0.5 \mathrm{M})$ and distilled with boric acid $(4 \%)$. Finally, the distilled sample was titrated with hydrochloric acid $(0.25 \mathrm{M})$.

\section{Determination of Carbohydrate, Starch, and Glucose Content}

The content of sugar moiety of carbohydrates was determined in accordance with the Lane and Eynon method, with some modification, as reported by Khan (28). The starch was calculated as difference.

\section{Determination of Ash Content}

Ash content was determined using the dry ashing technique with a muffle, in accordance to A.O.A.C (2000) method. Ten grams of grinded sample were weighed and introduced in the muffle apparatus at $550^{\circ} \mathrm{C}$. The ash content was expressed on dry basis and calculated using the following equation:

$$
\% \operatorname{Ash}(\text { dry basis })=(\mathrm{M} \text { ash } / \mathrm{M} \text { dry }) \mathrm{x} 100
$$

\section{Textural Properties}

Textural properties were evaluated according to Maktouf et al. (29) with some modifications. The analysis was conducted by Texture Analyser for foods (Zwick Roell). Samples were compressed with a plate probe using the same speed as the firmness measurement to $60 \%$ of strain, held for $30 \mathrm{~s}$, and then removed. The parameter recorded were: hardness, expressed as the peak force on first compression (Newton $[\mathrm{N}]$ ); springiness expressed as distance of the sample recovered after the first and the second compression ( $\mathrm{mm}$ ); the maximum compression force, was determined in both experimental and control samples.

\section{Microbiological Analyses}

An aliquot of DOF, and samples of experimental and control brioches were subjected to microbiological analyses. In detail, $1 \mathrm{~g}$ of DOF was diluted in sterile physiological water $(0.9 \%$ $\mathrm{NaCl})$ added with dimethyl sulfoxide $(5.0 \% \mathrm{w} / \mathrm{v})$. Serial diluted aliquots were inoculated into plates containing specific media and incubated at specific conditions, for counting different microbial groups. In details, Plate Count Agar (Sigma, Milan, Italy), incubated at $30^{\circ} \mathrm{C}$ for $72 \mathrm{~h}$ was used for mesophilic aerobic bacteria enumeration; Violet Red Bile Glucose Agar (Difco, Italy), aerobically incubated at $37^{\circ} \mathrm{C}$ for $24 \mathrm{~h}$, for Enterobacteriaceae; Mannitol Salt Agar, incubated at $37^{\circ} \mathrm{C}$ for 24-48 h, for staphylococci; Sabouraud Dextrose Agar, incubated at $25^{\circ} \mathrm{C}$ for $72 \mathrm{~h}$, for yeasts and mold and; Mc Conkey Agar (Liofilchem) incubated at $36^{\circ} \mathrm{C}$ for $24-28 \mathrm{~h}$ for Escherichia coli count.

Twenty-five grams of experimental and control brioches, collected at T0, T1, and T5 storage time, were diluted into sterile peptone-saline solution $(225 \mathrm{ml})$ and homogenized for $3 \mathrm{~min}$ in a Stomacher Lab Blender 400 (International PBI S.p.A Milan, Italy). Ten-fold dilutions were obtained and aliquots $(0.1 \mathrm{ml})$ were used for counting of total mesophilic bacteria and yeast and mold. Moreover, the detection of Bacillus cereus was carried out, according to International Standard specifies (30).

\section{Statistical Analyses}

Rheological characteristics were determined in triplicate and separately analyzed by using the Statistical package software Minitab $^{\mathrm{TM}}$ version 16.0. One-way analysis of variance (ANOVA) was performed on mean values and Fishers's test was carried out for the comparison of differences with an individual confidence interval of $95 \%$ and a simultaneous confidence level of $82.43 \%$. Differences between sample means were considered significant at $p \leq 0.05$.

Microbiological analyses were replicated twice for each experimental sample and sampling time, throughout storage. 
Microbial counts were expressed as $\log \mathrm{cfu} / \mathrm{g}$ and the results were reported as mean values \pm standard deviation. Data were subjected to analysis of variance (ANOVA) using the XLSTAT statistical software. $p \leq 0.05$ was considered statistically significant.

\section{RESULTS}

\section{Physico-Chemical Parameters}

A picture of control and experimental samples, obtained with different level of fat replacement, by DOF adding, right after the production, is shown in Figure 1.

Results of moisture determinations at different sampling times (T0, T1, and T5) of both experimental and control samples, stored at room temperature, are reported in Figure 2A. Data showed that experimental samples, obtained at different levels of fat replacement, showed higher moisture content than control samples, mostly after 5 days of storage (Figure 2A). These findings are in accordance to those related to weight losses (Table 2), which showed that experimental samples exhibited lower weight loss, compared to control, with DOF70\% showing the lowest value, followed by DOF 30\%.

Data of Aw, detected in samples during storage, did not show any significant variations among experimental samples: DOF $30 \%$ from $0.923 \pm 0.010$ (T0) to $0.905 \pm 0.004$ (T5); DOF $50 \%$ from $0.917 \pm 0.007$ (T0) to $0.905 \pm 0.00$ (T5); DOF $70 \%$ from $0.914 \pm 0.005$ (T0) to $0.904 \pm 0.003$ (T5). Whereas, a slight decrease in the control samples from $0.916 \pm 0.007$ (T0) to 0.899 \pm 0.013 (T5), mostly after 5 days of storage, was observed.

\section{Nutritional Properties}

Figure 2B shows the fat content of the different samples, expressed as percentage. Findings confirmed the highest fat content $(10 \%)$ of control samples and a decreasing of values in experimental samples obtained with increasing DOF adding. The value dropped to $2 \%$ in samples containing $70 \%$ of fiber.

Figure 2C shows that protein contents, detected in control samples resulted lower than in experimental samples, where protein content was proportionally related to the increase of added DOF.

Regarding starch and glucose contents, as shown in Figure 2D, a variation between the starch and glucose contents in experimental samples with lower added fiber, compared to control, was detected. In particular, samples added with 30 and $50 \%$ of DOF showed a lower content of both starch and glucose.

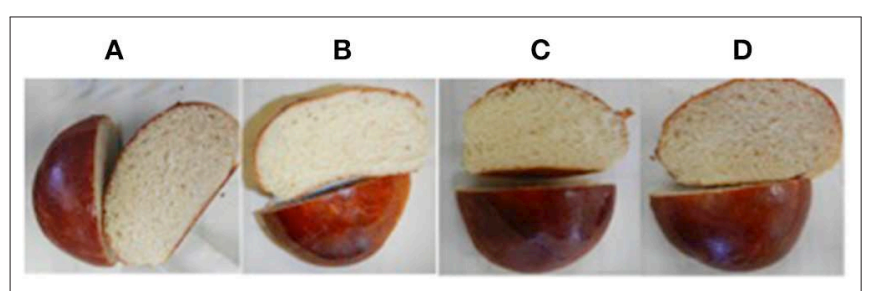

FIGURE 1 | (A) Brioches control; (B) Brioches added with 30\% of DOF; (C) Brioches added with $50 \%$ of DOF; (D) Brioches added with $70 \%$ of DOF.
Whereas, as shown in Figure 2E, no significant variations, between experimental and control samples, were observed both for total carbohydrate and starch content. Similar results were observed for ash content (Figure 2F).

In Table 3 are reported the nutritional parameters of both experimental and control brioche samples produced with different adding of DOF.

\section{Textural Properties}

The texture of DOF-added samples was evaluated during storage at room temperature. Compression tests showed that the experimental samples showed a more homogeneous resistance to breakage when compared to the control, during the whole storage period.

Table 4 shows that the softness of control samples, after the first day of storage, was lower than those found for all experimental samples, regardless the percentage of replacement of fat. Samples containing both 50 and $70 \%$ of DOF showed significant difference after 1 day from production, but not after 5 days of storage.

\section{Microbiological Results}

Results of microbiological analyses carried out on DOF samples revealed the absence of all researched microbial groups, with the exception of total mesophilic bacteria, which was recorded at a value of $4.70 \mathrm{log} \mathrm{cfu} / \mathrm{g}$ (data non shown).

Microbiological analyses of experimental and control brioche samples showed that all microbial groups, at T0 were present at densities lower than the detection limit. As reported in Table 5, at T1 sampling the total mesophilic bacteria was recorded at an average value of $3.0 \mathrm{log} \mathrm{cfu} / \mathrm{g}$ in all samples, except in samples obtained with $50 \%$ DOF, for which all microbial groups were below the detection limit (Table 5). Regarding yeast and mold, the lowest density ( $2.3 \mathrm{log} \mathrm{cfu} / \mathrm{g})$ was achieved in control samples while values of 2.71 and $3.02 \mathrm{log} \mathrm{cfu} / \mathrm{g}$ were counted in experimental samples with $70 \%$ and $30 \%$ of DOF, respectively. Regarding B. cereus a density of about $1 \mathrm{log}$ cfu/g was observed in all samples.

It is interesting to point out that after 5 days of storage significant differences were observed among control and experimental samples for all microbial groups, except for $B$. cereus, with an average increase of 3.4- and 1.6-log unit for yeast and mould and total mesophilic bacteria, respectively. On the contrary, no significant difference was detected in microbial counts in experimental samples obtained with 30 and $50 \%$ of added DOF (Table 5).

\section{DISCUSSION}

The addition of dietary fiber to bakery products represent a promising strategy to improve their nutritional quality. However high variability in fiber composition, functional and microbiological proprieties has been observed and mostly related to the applied extraction treatments. Extrusion-cooking, canning, grinding, boiling, can alter physico-chemical properties of fiber and, in some cases, improving its functionality. Lario et al. (10) demonstrated that dietary fiber opportunely obtained by 
A

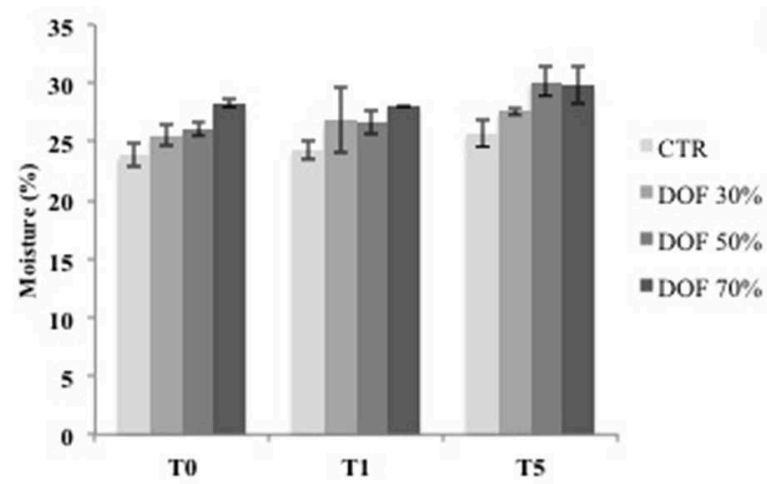

C

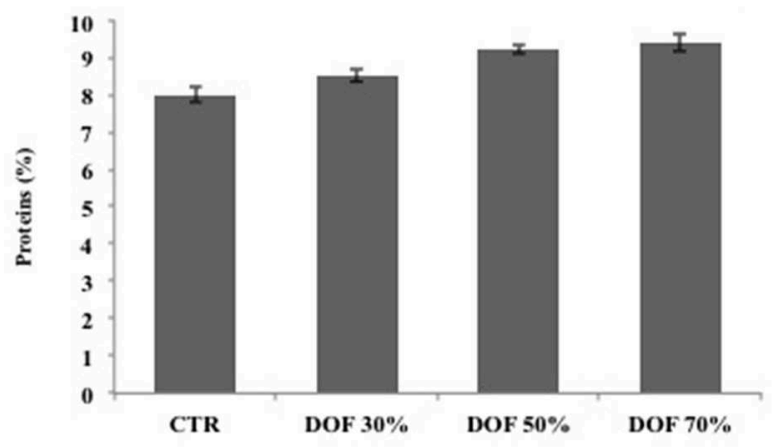

E

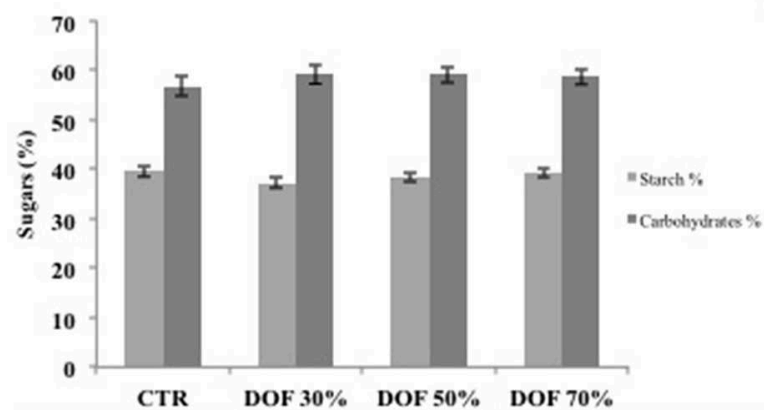

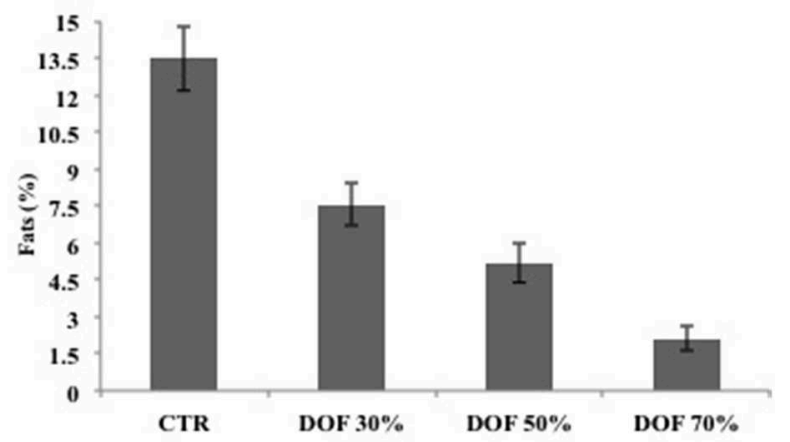

D

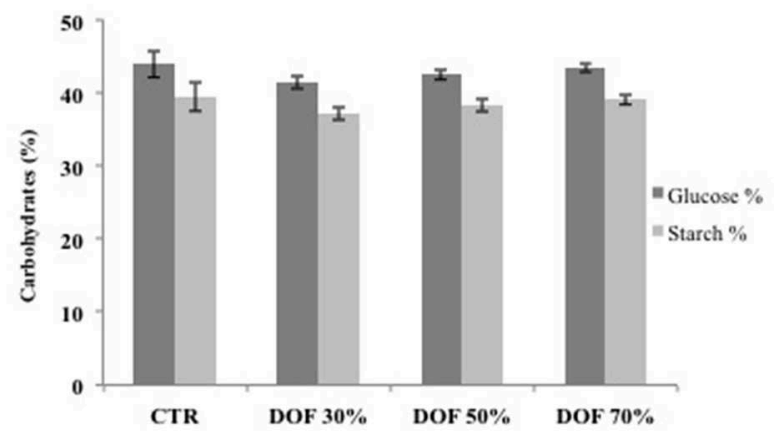

$\mathbf{F}$

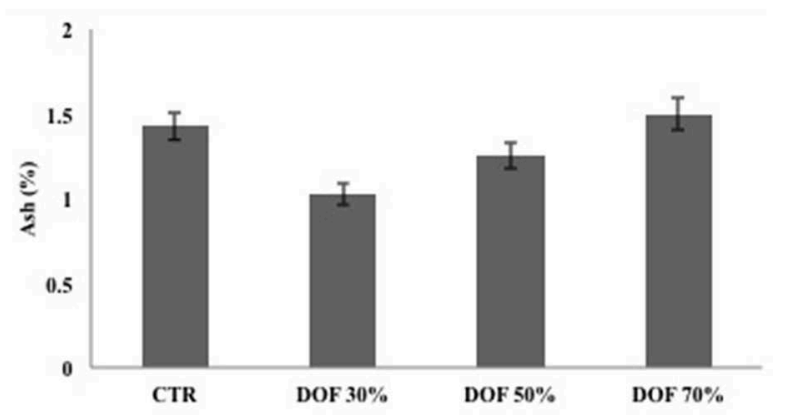

FIGURE 2 | (A) Moisture content at different times of storage in brioches control and added with DOF; (B) Fats content in brioches control and added with different quantity of DOF; (C) Proteins content in control brioches and with different quantity of DOF; (D) Glucose and starch content in control brioches and with different quantity of DOF; (E) Carbohydrates and starch content in control brioches and with different quantity of DOF; (F) Ash content in control brioches and with different quantity of DOF.

lemon waste showed good functional, microbiological, and physico-chemical characteristics. Larrauri (31) showed that fiber content fiber of powder obtained from mango peels was affected by the particle size and time of peels washing, while Larrea et al. (32) reported that the extrusion process positively modified functional and structural properties of fiber obtained from orange pulp.

In the present work, a debittered orange fiber (DOF) was extracted from orange juice by-products, and produced in a pilot scale. The technique applied for DOF production reduced the limonoids content that contributes to bitterness of fiber, strongly compromising its usability $(33,34)$. In addition the final spry-drying, allowed obtaining a product with a low Aw value $(0.24)$ that inhibits the microbial growth, making the DOF a microbiological stable and a safe product. The presence of mesophilic aerobic bacteria, in this case, represents an indicator of hygiene process and could be related to packages and/or to erroneous manipulation in post processing phases. The European 
Food Safety Authority (35) reported that the different physicochemical characteristics of a fiber are not only related to its fermentability and other physiological effects, but mainly to bulking property due to the water holding capacity (36). The DOF here obtained showed good functional properties with a high water and oil holding capacities, which are the most important functional parameter for the employ of fiber in bakery product (37).

Brioches are semi-preserved foods, and their stability depends on a variety of factors such as moisture content, process, storage temperature and presence of chemical additives or stabilizers. In the present study different levels of DOF were used as fat replacer in brioches and the effects on physico-chemical, technological, nutritional, and microbiological properties were evaluated at different time of storage at room temperature. The addition of fibers, besides improving nutritional characteristics, leads an overall improvement, mainly from a technological point of view,

TABLE 2 | Changes of weight during storage and relative weight losses.

\begin{tabular}{lcrrr}
\hline Sample & T0 & T1 & T5 & $\begin{array}{c}\text { Weight } \\
\text { loss (\%) }\end{array}$ \\
\hline CTR & $103.21^{\mathrm{a}} \pm 4.48$ & $99.15^{\mathrm{a}} \pm 3.04$ & $98.63^{\mathrm{a}} \pm 4.69$ & 4.43 \\
DOF & $118.92^{\mathrm{b}} \pm 3.19$ & $116.79^{\mathrm{b}} \pm 0.35$ & $115.43^{\mathrm{b}} \pm 1.38$ & 2.93 \\
30\% & & & & \\
DOF & $113.92^{\mathrm{b}} \pm 2.47$ & $112.57^{\mathrm{b}} \pm 4.26$ & $109.96^{\mathrm{b}} \pm 4.33$ & 3.47 \\
$50 \%$ & & & & \\
DOF & $116.96^{\mathrm{b}} \pm 0.06$ & $114.79^{\mathrm{b}} \pm 0.35$ & $114.90^{\mathrm{b}} \pm 5.68$ & 1.76 \\
$70 \%$ & & & &
\end{tabular}

${ }^{a, b}$ Mean values with different letter in superscript within columns indicates significant differences $(p \leq 0.05)$ due to different percentage of DOF.

TABLE 3 | Nutritient composition of brioches.

\begin{tabular}{lcccc}
\hline Parameter & DOF 30\% & DOF 50\% & DOF 70\% & CTR \\
\hline Total dietary fiber (\%) & 3.99 & 6.65 & 9.31 & - \\
Fat (\%) & 6.00 & 4.50 & 2.0 & 10.00 \\
Protein (\%) & 8.50 & 9.20 & 9.40 & 8.00 \\
Carbohydrates (\%) & 58.98 & 58.97 & 58.54 & 56.69 \\
$\quad$ of which sugars (\%) & 21.85 & 20.7 & 19.46 & 17.2 \\
$\quad$ of which starch (\%) & 37.13 & 38.27 & 39.08 & 39.49 \\
Ash (\%) & 1.02 & 1.25 & 1.50 & 1.43
\end{tabular}

according to Martins et al. (38). In particular, the replacement of fat with DOF produced positive effects, arising brioches with higher moisture contents, higher protein and similar activity water and carbohydrates values than controls, confirming that fat replacement with DOF is a strategy suitable firstly to increase fiber and secondly to reduce fat contents $(39,40)$. In bakery confectionary products, carbohydrate, starch and glucose are of great importance, representing the main constituent that can give rise to qualitative changes during storage. The addition of DOF do not influence the content in both starch and glucose, moreover no variation was observed in total carbohydrate content. The experimental samples showed, also, improved rheological properties, Fmax values and their differences are lower respect to the control, as confirmed by compression test, and good microbiological characteristics, mainly within the first day from production, which is the most frequent time of consumption. Moreover, although lipids represent secondary ingredients, they perform important technological functions in doughs, such as aeration, gas retention in glutinous mesh, plasticizing action, anti-stress action, improvement of sensory characteristics and lubricating action, their replacement with DOF did not affect rheological proprieties of final products. Here the replacement of fat, with different percentages of DOF, resulted in a decrease of fat up to $2 \%$, in samples containing $70 \%$ of fiber. Crizel et al. (41) evaluated the application of fibers originated from orange waste as a fat replacer in ice cream obtained final products with a $70 \%$ reduction of fat, without any significant changes in color, odor and texture. The incorporation of orange fiber by-products in fresh pasta was also recently considered and results showed an increase of both antioxidant capacity and fiber content in final product, without any detrimental effect (24).

In the present study, DOF was incorporated at higher amount than in previous studies $(42,43)$ and experimental brioches showed higher content of protein, and lower percentage of ash (at 30 and $50 \%$ of fat replacement) in discordance to findings reported by Nassar et al. (40).

For brioches, as for other bakery confectionary products, with high or intermediate moisture content, microbial spoilage is often the major factor limiting the shelf life and a major cause of economic loss (44). The artisanal brioches are supposed to be consumed as fresh products and are daily produced for direct sales, without any packages. For this reason, they are mainly susceptible to post baking contamination, mainly by mould, that are microrganisms well-adapted to xerophilic conditions (45). The contamination can occur by bakery surfaces

TABLE 4 | Cyclic compression test for brioches during storage time.

\begin{tabular}{|c|c|c|c|c|c|c|c|c|c|}
\hline \multirow{2}{*}{$\begin{array}{l}\text { Samples } \\
\text { Cycles }\end{array}$} & \multicolumn{3}{|c|}{ T0 } & \multicolumn{3}{|c|}{ T1 } & \multicolumn{3}{|c|}{ T5 } \\
\hline & I & II & III & I & II & III & I & II & III \\
\hline DOF 30\% & $17.6^{d} \pm 0.85$ & $18.5^{d} \pm 1.13$ & $18.7^{d} \pm 1.13$ & $26.55^{d} \pm 1.77$ & $27.7^{d} \pm 1.41$ & $29.15^{d} \pm 0.07$ & $34.5^{c} \pm 0.99$ & $38.85^{c} \pm 0.64$ & $40.75^{c} \pm 3.18$ \\
\hline DOF 50\% & $31.55^{b} \pm 0.64$ & $33.05^{b} \pm 1.48$ & $33.95^{b} \pm 1.34$ & $37.35^{\mathrm{c}} \pm 2.90$ & $40.75^{c} \pm 2.47$ & $43.01^{c} \pm 3.82$ & $60.15^{b} \pm 6.43$ & $58.75^{b} \pm 0.35$ & $64.85^{b} \pm 1.48$ \\
\hline DOF 70\% & $25.2^{\mathrm{c}} \pm 3.96$ & $26.25^{\mathrm{c}} \pm 5.02$ & $25.7^{\mathrm{c}} \pm 4.53$ & $43.45^{b} \pm 1.91$ & $46.45^{b} \pm 4.31$ & $47.7^{b} \pm 5.8$ & $59.8^{b} \pm 1.98$ & $69.55^{b} \pm 6.29$ & $86.05^{\mathrm{a}} \pm 5.52$ \\
\hline CTR & $46.0^{\mathrm{a}} \pm 4.81$ & $52.0^{\mathrm{a}} \pm 8.06$ & $54.2^{a} \pm 6.36$ & $50.95^{a} \pm 0.49$ & $85.5^{\mathrm{a}} \pm 1.27$ & $79.25^{\mathrm{a}} \pm 1.2$ & $66.3^{\mathrm{a}} \pm 0.57$ & $85.5^{a} \pm 1.13$ & $104.5^{\mathrm{a}} \pm 2.12$ \\
\hline
\end{tabular}

The results are expressed as $F(N)$ and compressed to $50 \%$ strain.

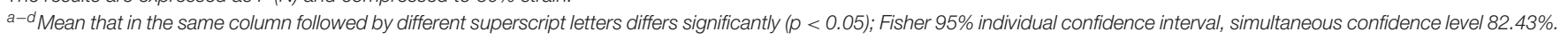


TABLE 5 | Microbial counts and standard deviation detected in experimental and control samples during storage.

\begin{tabular}{|c|c|c|c|c|c|c|}
\hline & \multicolumn{3}{|c|}{ T1 } & \multicolumn{3}{|c|}{ T5 } \\
\hline DOF 30\% & $3.02 \pm 0.03^{b}$ & $3.02 \pm 0.03^{c}$ & $1.02 \pm 0.01^{b}$ & $4.95 \pm 0.01^{b}$ & $4.91 \pm 0.01^{b}$ & $1.86 \pm 0.02$ \\
\hline DOF 50\% & $<1^{\mathrm{a}}$ & $<1^{a}$ & $<1^{\mathrm{a}}$ & $4.86 \pm 0.02^{b}$ & $4.95 \pm 0.01^{b}$ & $1.82 \pm 0.01$ \\
\hline
\end{tabular}

${ }^{a-c}$ Mean values with different letter in superscript within columns indicates significant differences $(p \leq 0.05)$ due to different percentage of DOF.

and equipment, by food handlers, and, above all, by raw ingredients (44). Mould spoilage are more troublesome during the summer months, due to the warmer and more humid storage conditions. A major source of Bacillus contamination is represented by raw ingredients (e.g., flour, sugar, and leaven), and the microorganism survives the baking process, germinates upon cooling, and grows under both aerobic and anaerobic conditions. Results obtained from microbiological analyses confirmed the antimicrobial effects reported for natural extracts from fruit and vegetables by-products that may contain antimicrobial agents, and thus used as an additional control measure to guarantee the food safety (5)

The amount of fiber in the food can vary from $(46)<0.2 \mathrm{~g}$ to $20 \mathrm{~g} /$ serving and the EU Regulation (EC) No 1924/2006 specifies the use of the term "source of fiber" as referred to products containing at least $3 \mathrm{~g}$ of fiber per $100 \mathrm{~g}$ and the terms "high in fiber" as referred to product containing at least $6 \mathrm{~g}$ of fiber per $100 \mathrm{~g}$. Results of present work demonstrated that the flat replacement with DOF at $50 \%$ produced brioche with final dietary fiber content enough to be referred as brioches with high fiber content. Many experts recommend a total dietary fiber intake of 25-30 grams per day end (35), proposed that a fiber intake of $25 \mathrm{~g} / \mathrm{d}$ would be adequate for normal laxation in adults whereas more than $25 \mathrm{~g} / \mathrm{d}$ is required to reduce risk of coronary heart disease, type 2 diabetes and improved weight maintenance (36). Surveillance data showed that dietary fiber intakes, among adults in Italy, is estimated around $19 \mathrm{~g} / \mathrm{d}$ (47) and any effort must be done in order both to promote consumption of food with high fiber content and to offer fortified products with good quality traits. Taking into account the recommended daily intake of dietary fiber, the consumption of one brioche obtained with the $50 \%$ of fat replacement, can cover from 21.6 to $25.2 \%$ and from 23.65 to $30,28 \%$ the recommended daily amount for men and women, respectively.

\section{CONCLUSION}

An increasing attention has been globally paid on the utilization of fruit processing by-products that could be converted into edible products and/or ingredients. Such a use contributes to a better utilization of important resources and has recently resulted in the appearance of commercial various new ingredients, mainly containing dietary fiber. The use of by-products is of interest, both for reducing industrial environmental contamination and increasing functional, technological and nutritional properties of food. The present study demonstrated that the addition of debittered orange fiber resulted compatible with bakery products processing enhancing stability of final products. In addition, the fat strategy replacing, improved nutritional traits of a bakery confectionary product largely consumed in Italy, leading the obtaining a low-fat brioches fortified with natural fiber.

\section{DATA AVAILABILITY STATEMENT}

The raw data supporting the conclusions of this article will be made available by the authors, without undue reservation, to any qualified researcher.

\section{AUTHOR CONTRIBUTIONS}

CC, CR, and SB: substantial contributions to the conception and design of the work, acquisition, analysis, and interpretation of data. RP, NR, RT, and AT: acquisition, analysis and interpretation of data. CC, RP, and CR: drafting the work and revising it critically for intellectual content. All authors approved the final version of the manuscript to be submitted for publication and agreed to be accountable for all aspects of the work in ensuring that questions related to the accuracy and integrity of any part of the work are appropriately investigated and resolved.

\section{FUNDING}

This work was partially supported by the industrial project Uso sostenibile dei sottoprodotti della lavorazione industriale degli agrumi: founded by Ministero dello Sviluppo Economico (MISE). After acceptance the fees are covered by the MISE project of Dipartimento di Agricoltura, Alimentazione e Ambiente of University of Catania, funding code BRSA01 CITROFOOD; CUP:B88C14000460008.

\section{ACKNOWLEDGMENTS}

This work was partially carried out within the industrial project Uso sostenibile dei sottoprodotti provenienti dalla lavorazione industriale degli agrumi Ministero dello Sviluppo Economico (MISE). Authors thank Mr. Bella for kindly providing brioches samples. 


\section{REFERENCES}

1. Nicklas TA, Drewnowski A, O’Neil CE. The nutrient density approach to healthy eating: challenges and opportunities. Pub Health Nutr. (2014) 17:2626-36. doi: 10.1017/S136898001400158X

2. Vlassopoulos A, Masset G, Leroy F, Hoover C, Chesneau-Guillemont C, Leroy F, et al. A nutrient profiling system for the (re)formulation of a global food \& beverage portfolio. Eur J Nutr. (2017) 56:110522. doi: 10.1007/s00394-016-1161-9

3. Jeddou KB, Chaari F, Maktouf S, Nouri-Ellouz O, Helbert CB, Ghorbel RE. Structural, functional, and antioxidant properties of water-soluble polysaccharides from potatoes peels. Food Chem. (2016) 15:205-97. doi: 10.1016/j.foodchem.2016.02.108

4. Sharma SK, Bansal S, Mangal M, Dixit AK, Gupta RK, Mangal AK. Utilization of food processing by-products as dietary, functional, and novel fiber: A review. Crit Rev Sci Nutr. (2016) 56:1647-61. doi: 10.1080/10408398.2013.794327

5. Kowalska H, Czajkowska K, Cichowska J, Lenart A. What's new in biopotential of fruits and vegetable by-products applied in the food processing industry. Trends Food Sci Technol. (2017) 67:150-9. doi: 10.1016/j.tifs.2017.06.016

6. FAOSTAT (2015). Available online at: http://fao.org/faostat/es/\#data/QC

7. USDA Foreign Agricultural Service (2017). Available online at: https://www. fas.usda.gov

8. Shiming LI, Chih YL, Chi TH. Hydroxylated polymethoxy-flavones and methylated flavonoids in sweet orange (Citrus sinensis) peel. J Agric Food Chem. (2006) 54:4176-85. doi: 10.1021/jf060234n

9. Mamma D, Christakopoulos P. Biotransformation of citrus byproducts into value added products. Waste Biomass Valori. (2014) 5:529-49. doi: 10.1007/s12649-013-9250-y

10. Lario Y, Sendra E, García-Pérez J, Fuentes C, Sayas-Barberá E, Fernández- López J, et al. Preparation of high dietary fiber powder from lemon juice by-products. Innov Food Sci Emerg Technol. (2004) 5:113-7. doi: 10.1016/j.ifset.2003.08.001

11. Fernández-López J, Fernández-Ginés JM, Alesón-Carbonell L, Sendra E, Sayas Barberá ME, Pérez Álvarez JA. Application of functional citrus by-products to meat products. Trends Food Sci Technol. (2004) 15:17685. doi: 10.1016/j.tifs.2003.08.007

12. Rezzadori K, Benedetti S, Amante ER. Proposals for the residues recovery: orange waste as raw material for new products. Food Bioprod Process. (2012) 9:606-14. doi: 10.1016/j.fbp.2012.06.002

13. Abbate E, Palmeri R, Todaro A, Blanco RM, Spagna G. Production of a $\alpha$-L-rhamnosidase from aspergillus terreus using citrus solid waste as inducer for application in juice industry. Chem Eng Trans. (2012) 27:2538. doi: 10.3303/CET1227043

14. Parhiz H, Roohbakhsh A, Soltani F, Rezaee R, Iranshahi M. Antioxidant and anti-inflammatory properties of the citrus flavonoids hesperidin and hesperitin: an updated review of their molecular mechanisms and experimental models. Phytother Res. (2015) 29:323-31 doi: 10.1002/ptr.5256

15. Mirabella N, Castellani V, Sala S. Current options for the valorization of food manufacturing waste: a review. J Clean Prod. (2014) 65:2841. doi: 10.1016/j.jclepro.2013.10.051

16. Figuerola F, Hurtado ML, Estévez AM, Chiffelle I, Asenjo F. Fibre concentrates from apple pomace and citrus peel as potential fibre sources for food enrichment. Food Chem. (2005) 91:395-401. doi: 10.1016/j.foodchem.2004.04.036

17. Kale M, Pai AD, Hamaker B, Campanella O. Incorporation of fibers in foods: A food engineering challenge. In: Aguilera AM, Barbosa-Canovas GV, Simpson R, Welti-Chanes J, Bermudez AguirreD, editors. Food Engineering Interfaces. New York, NY: Springer (2011) 69-98.

18. Rodríguez R, Jiménez A, Fernández-Bolaños J, Guillén R, Heredia A. Dietary fibre from vegetable products as source of functional ingredients. Trends Food Sci Technol. (2006) 17:3-15. doi: 10.1016/j.tifs.2005.10.002

19. Tudorica CM, Kuri V, Brennan CS. Nutritional and physicochemical characteristics of dietary fiber enriched pasta. J Agric Food Chem. (2002) 50:347-56. doi: 10.1021/jf0106953

20. Dhingra D, Michael M, Rajput H, Patil RT. Dietary fiber in foods: a review. J Food Sci Technol. (2011) 49:255-66. doi: 10.1007/s13197-0110365-5
21. Grajek W, Olejnik A, Sip A. Probiotics, prebiotics and antioxidants as functional foods. Acta Biochim Pol. (2005) 52:665-71. doi: 10.18388/abp.2005_3428

22. Greenwald P, Clifford CK, Milner JA. Diet and cancer prevention. Eur J Cancer. (2001) 37:948-65. doi: 10.1016/S0959-8049(01)00070-3

23. Sharif MK, Butt MS, Anjum FM, Nawaz H. Preparation of fiber and mineral enriched deffated rice bran supplemented cookies. Pak J Nutr. (2009) 8:5717. doi: 10.3923/pjn.2009.571.577

24. Crizel TM, Rios AO, Thys RCS, Flôres SH. Effects of orange by-product fiber incorporation on the functional and technological properties of pasta. Food Sci Tech Campinas. (2015) 35:546-51. doi: 10.1590/1678-457X.6719

25. O'Shea N, Arendt EK, Gallagher E. Dietary fibre and phytochemical characteristics of fruit and vegetable by-products and their recent applications as novel ingredients in food products. Innov Food Sci Emerg Technol. (2012) 16:1-10. doi: 10.1016/j.ifset.2012.06.002

26. Singleton VL, Rossi JA. Colorimetry of total phenolics with phosphomolybdic-phosphotungstic acid reagents. Am J Enol Viticult. (1965) 16:144-53.

27. Association of Official Analytical Chemists (AOAC). Official Methods of Analysis, 15th ed., Vol. 2, Arlington, VA: AOAC, Inc. (1990).

28. Khan TH. Titrimetric determination of reducing sugars with copper (II) sulphate. Analyst. (1979) 104:261-5. doi: 10.1039/an9790 400261

29. Maktouf S, Jeddou KB, Moulis C, Hajji H, Remaud-Simeon M, EllouzGhorbel R. Evaluation of dough rheological properties and bread texture of pearl millet-wheat flour mix. J Food Sci Technol. (2016) 53:206166. doi: 10.1007/s13197-015-2065-z

30. EN ISO 7932:2004. Microbiology of Food and Animal Feeding Stuffs Horizontal Method for the Enumeration of Presumptive Bacillus cereus Colony-Count Technique at $30^{\circ} \mathrm{C}$ (ISO 7932:2004) Technical Committee: ISO/TC 34/SC 9 Microbiology (2020).

31. Larrauri JA. New approaches in the preparation of high dietary fibre powder from fruit by- products. Trends Food Sci Technol. (1999) 10:38. doi: 10.1016/S0924-2244(99)00016-3

32. Larrea MA, Chang YK, Martinez-Bustosc F. Some functional properties of extruded orange pulp and its effect on the quality of cookies. LWT-Food Sci Technol. (2005) 3:213-20. doi: 10.1016/j.lwt.2004.05.014

33. Todaro A, Rosa Palmeri R, Scalone D, Giuseppina RA, Alberio GRA, Serafini $\mathrm{M}$, et al. Removal of bitter compounds from citrus byproducts. Ital J Food Sci. (2013) 25:465-9.

34. Rouseff RL, Fisher JF. Determination of limonin and related limonoids in citrus juices by high performance liquid chromatography. Anal Chem. (1980) 52:1228-33. doi: 10.1021/ac50058a017

35. EFSA Panel on Dietetic Products, Nutrition and Allergies (NDA). Scientific Opinion on the substantiation of health claims related to dietary fiber (ID 744, 745, 746, 748, 749, 753, 803, 810, 855, 1415, 1416, 4308, 4330) pursuant to Article 13(1) of Regulation (EC) No 1924/2006. EFSA J. (2010) 8:1735. doi: 10.2903/j.efsa.2010.1735

36. Stephen AM, Champ MM-J, Cloran SJ, Fleith M, van Lilou L, Mejborn H, et al. Dietary fiber in Europe: current state of knowledge on definitions, sources, recommendations, intakes and relationships to health. Nutr Res Rev. (2017) 30:149-90. doi: 10.1017/S095442241700004X

37. Lundberg B, Pan X, White A, Chau H, Hotchkiss A. Rheology and composition of citrus fiber. J Food Eng. (2014) 125:97104. doi: 10.1016/j.jfoodeng.2013.10.021

38. Martins ZE, Pinho O, Ferreira IMPLVO. Food industry by-products used as functional ingredients of bakery products. Trends Food Sci Technol. (2017) 67:106-28. doi: 10.1016/j.tifs.2017.07.003

39. Martin K. Replacing fat, retaining taste. Food Eng Int. (1999) 24:57-9.

40. Nassar AG, Abd El-Hamied AA, El-Naggar EA. Effect of citrus by-products flour incorporation on chemical, rheological and organoleptic characteristics of biscuits. World J Agric Sci. (2008) 4:612-6.

41. Crizel TM, Jablonski A, Rios AO, Rech R, Flôres SH. Dietary fiber from orange byproducts as a potential fat replacer. LWT-Food Sci Technol. (2013) 53:9-14. doi: 10.1016/j.lwt.2013.02.002

42. Kucerova J, Šottníková V, Nedomová Š. Influence of dietary fibre addition on the rheological and sensory properties of dough and bakery products. Czech J Food Sci. (2013) 4:340-6. doi: 10.17221/352/2012-CJFS 
43. Singh R. Development of fiber enriched bakery products by incorporating fruit pulp waste powder and their acceptability evaluation. Int J Adv Res Biol Sci. (2016) 3:222-6. Available online at: http://s-o-i.org/1.15/ijarbs-20163-6-30

44. Saranraj P, Geetha M. Microbial spoilage of bakery products and its control by preservatives. Int J Pharm Biol Arch. (2012) 3:38-48.

45. Fustier $\mathrm{P}$, Lafond A, Champagne CP, Lamarche F. Effect of inoculation techniques and relative humidity on the growth of molds on the surfaces of yellow layer cakes. Appl Environ Microbiol. (1998) 64:192-6. doi: 10.1128/AEM.64.1.192-196. 1998

46. European Parliament. Regulation (EC) No. 1924/2006 of the European Parliament and of the Council of 20 December 2006 on nutrition and health claims made on foods. Off $J$ Eur Union. (2006) 404:9.
47. EU Science Hub (2018). Available online at: https://ec.europa.eu/jrc/en/ health-knowledge-gateway/promotion-prevention/nutrition/fibre (accessed on October 30, 2018).

Conflict of Interest: The authors declare that the research was conducted in the absence of any commercial or financial relationships that could be construed as a potential conflict of interest.

Copyright (C) 2020 Caggia, Palmeri, Russo, Timpone, Randazzo, Todaro and Barbagallo. This is an open-access article distributed under the terms of the Creative Commons Attribution License (CC BY). The use, distribution or reproduction in other forums is permitted, provided the original author(s) and the copyright owner(s) are credited and that the original publication in this journal is cited, in accordance with accepted academic practice. No use, distribution or reproduction is permitted which does not comply with these terms. 